УДК 339.1

\title{
ПРЯМИЙ МАРКЕТИНГ ЯК ІНТЕРАКТИВНА МАРКЕТИНГОВА СИСТЕМА РОЗПОДІЛУ ТУРИСТИЧНИХ ПОСЛУГ
}

\section{DIRECT MARKETING AS AN INTERACTIVE MARKETING SYSTEM FOR THE DISTRIBUTION OF TOURIST SERVICES}

\author{
Ільченко Тетяна Вікторівна \\ кандидат економічних наук, доцент, \\ Дніпровський державний аграрно-економічний університет \\ ORCID: https://orcid.org/0000-0003-1879-6310 \\ Ilchenko Tetiana \\ Dnipro State Agrarian and Economic University
}

Прямий маркетинг передбачає розповсюдження продуктів, інформаційних та рекламних переваг для клієнтів через інтерактивну роботу. Причина популярності прямого маркетингу в технічних досягненнях, таких як управління відносинами 3 клієнтами та Інтернет-маркетингу, які дозволяють прямий контакт 3 цільовими споживачами. Метою статті стало обґрунтування техніки прямого маркетингу як інтерактивної маркетингової системи розподілу туристичних послуг з метою підвищення конкурентоспроможності туризму. Прямий маркетинг характеризується високою точністю у отриманні швидких і прямих відповідей споживачів, і легкому вимірюванні маркетингових результатів. Прямий маркетинг ґрунтується на базах даних та списках потенційних користувачів послуг, стає все більш доступним для маркетологів. В статті визначено переваги та недоліки прямого маркетингу як інтерактивної маркетингової системи розподілу туристичних послуг.

Ключові слова: маркетингові інструменти, прямий маркетинг, маркетингова система розподілу, туристичні послуги, конкурентоспроможність туристичної галузі.

Прямой маркетинг предусматривает распространение продуктов, инорормационных и рекламных преимуществ для клиентов через интерактивную работу. Причина популярности прямого маркетинга в технических достижениях, таких как управление отношениями с клиентами и Интернет-маркетинга, которые позволяют прямой контакт с целевыми потребителями. Целью статьи - обоснование техники прямого маркетинга как интерактивной маркетинговой системы распределения туристических услуг с целью повышения конкурентоспособности туризма. Прямой маркетинг характеризуется высокой точностью в получении быстрых и прямых ответов потребителей, и легком измерении маркетинговых результатов. Прямой маркетинг основывается на базах данных и списках потенциальных пользователей услуг становится все более доступным для маркетологов. В статье определены преимущества и недостатки прямого маркетинга как интерактивной маркетинговой системы распределения туристических услуг.

Ключевые слова: маркетинговые инструменты, прямой маркетинг, маркетинговая система распределения, туристические услуги, конкурентоспособность туристической отрасли.

Direct marketing involves the distribution of products, information and advertising benefits for customers through interactive work (communication). The reason for the popularity of direct marketing is in technical advances, such as customer relationship management and Internet marketing that allow direct contact with target consumers. The aim of the article was to substantiate the technique of direct marketing as an interactive marketing system for the distribution of tourist services in order to increase the competitiveness of tourism. Direct marketing is characterized by high accuracy in obtaining quick and direct consumer responses, and easy measurement of marketing results. Direct marketing is based on databases and lists of potential customers (users) of services, is becoming increasingly available to marketers. To assess the state of tourism in Ukraine and further to characterize the direct marketing as an interactive marketing system for the distribution of tourism services it was analyzed the dynamics of tourism flows in Ukraine. During 2015-2019, the number of tourists served by tour operators, travel agents increased by 4 million people. The number of foreign tourists visiting Ukraine increased by almost 72,000, and the number of tourists traveling abroad increased by 3.9 million. Domestic flows of tourists also show stable growth dynamics during the study 
period (2015-2019). In the article there are identified the advantages and disadvantages of direct marketing as an interactive marketing system for the distribution of tourist services. Sustainable market competitiveness of the tourism industry requires a balance of growth orientation and commitment to the environment with an acceptable rate of return for all industry partners involved in destination marketing. Any changes in the distribution systems of tourism can be stimulated by external macro-factors, such as politics and trade, the global and national economy, technological innovation and access to them. In the near future, the tourism market will definitely introduce new technologies and opportunities; as many venture capital firms invest more and more in innovation.

Keywords: marketing tools, direct marketing, marketing distribution system, tourism services, competitiveness of the tourism industry.

Постановка проблеми. Маркетинг туризму $€$ систематичною адаптацією політики туристичного бізнесу на місцевому, регіональному, національному та міжнародному рівнях для задоволення потреб туристів і отримання прибутку. Оцінюючи стратегії розподілу, туристична індустрія повинна вивчити питання контролю та співвідношення ціни та якості. Крім того, розвиток мобільних пристроїв та їх додатків надає широкий спектр можливостей туристичній індустрії [10]. Туристичний бізнес повинен продовжувати використовувати інноваційні технології прямого маркетингу як інтерактивної маркетингової системи розподілу туристичних послуг, щоб покращити досвід клієнтів.

Аналіз останніх досліджень і публікацій. Актуальні проблеми маркетингу туристичних послуг були в центрі уваги багатьох вітчизняних та зарубіжних вчених. Так, Maxim Polyakov, Vladimir Bilozubenko, Natalia Nebaba, Maxim Korneyev and Yelyzaveta Saihak досліджували туризм як важливу частину економіки всіх країн-членів ЄС. В останні десятиліття в європейській економіці та в усьому світі індустрія туризму динамічно розвивалася. Однак у 2019-2020 рр. виникло багато нових викликів, пов'язаних 3 наслідками економічної рецесії та кризи COVID-19, що знизило стійкість та показники індустрії туризму. Крім того, спираючись на встановлені повноваження $€ С$, його туристична політика доповнює дії національних урядів, які також забезпечують диференційований підхід до розвитку національних туристичних галузей. 3 огляду на, з одного боку, необхідність спільного курсу на підтримку туризму, а з іншого боку, специсріку окремих країн, обов'язковою умовою наднаціональної політики в цій сорері $€$ врахування асиметрії індустрії туризму в країнах-членах $€ C$.

Zuzana Vaculčikova, Zuzana Tučkova and Xuan Thanh Nguyen стверджують, що одним із радикальних інструментів, що змінили світ маркетингу, є поява цифрової епохи, яка надзвичайно змінила світ маркетингу, продажів, та поведінки споживачів. Для бізнесу це набагато зручніше розміщувати товари чи послуги в Інтернеті, залучати клієнтів, отримувати відгуки від них, стежити за зростанням або зменшенням попиту, націлювати маркетинг на охоплення конкретних цільових груп в Інтернеті, і завдяки різному управлінському програмному забезпеченню моніторити поточні та прогнозувати майбутні доходи.

Olena Sushchenko and Matthnai Ekouaghe пишуть, що до появи Інтернету туристи прямували безпосередньо у місцеві туристичні агентства, щоб забронювати поїздки. Ціни були лінійними, оскільки майже не було конкуренції. Коли з'явився Інтернет, авіакомпанії почали продавати авіаквитки безпосередньо пасажирам і необхідність посередництва зникла. Крім того, почала виникати дуже висока конкуренція. Необхідно мати на увазі, що сьогодні туристи мають багато інформації, щоб прийняти найкраще рішення про покупку. Існує велика кількість веб-сайтів і каналів, де компанії можуть звітувати та порівнювати ціни, і все це можна робити одночасно на кількох пристроях.

Виділення невирішених раніше частин загальної проблеми. Ступінь вивчення проблеми прямого маркетингу відносно високий, враховуючи той фракт, що ця тема стосується готелів, туристичних послуг, електронної комерції тощо. Прямий маркетинг ґрунтується на базах даних та списках потенційних клієнтів (користувачів) послуг, стає все більш доступним для маркетологів. Існує необхідність удосконалення маркетингових методів та практики використовуваних на туристичному ринку, потім вивчати нові тенденції маркетингу, які сприяли розвитку використання маркетингових технологій у ссрерах послуг туристичної індустрії.

Формулювання цілей статті. Метою статті $€$ обґрунтування техніки прямого маркетингу як інтерактивної маркетингової системи розподілу туристичних послуг з метою підвищення конкурентоспроможності туризму. Предметом дослідження в галузі туристичних послуг є процес постійного розширення, оскільки швидкий розвиток впливає на створення нових та модернізацію існуючих методів прямого маркетингу.

Виклад основного матеріалу. Всесвітньо визнаним авторитетом у сорері маркетингу $\epsilon$ американська маркетингова Асоціація (AMA), 
яка у своєму одномовному словнику характеризує маркетинг як фрункцію організації та сукупності процесів створення, спілкування та надання цінності клієнтам та розвиток відносин 3 клієнтами таким чином, що вони приносять користь компанії та власникам своїх акцій [5]. Всі ці характеристики та визначення мають кілька спільних знаменників. Зокрема, це роль маркетингу, як концепції або інструменту, що пов'язує ринок і замовника 3 компанією (або організацією, регіоном тощо), створюючи пропозицію (продукт, послугу, ідею) [11].

Для оцінки стану туристичної діяльності в Україні і в подальшому характеристики прямого маркетингу як інтерактивної маркетингової системи розподілу туристичних послуг проаналізуємо динаміку туристичних потоків в Україні (табл. 1).

Аналізуючи дані таблиці 1, можна зробити висновок, що протягом 2015-2019 років кількість туристів, обслуговуваних туроператорами, турагентами зросла на 4 млн осіб. Кількість іноземних туристів, які відвідали Україну збільшилась майже на 72 тис. осіб, а кількість туристів, що виїжджали за кордон, зросла на 3,9 млн осіб. Внутрішні потоки туристів також показують стабільну динаміку зростання протягом досліджуваного періоду (2015-2019 роки).

Прямий маркетинг - це будь-який маркетинг, який ґрунтується на прямому спілкуванні або розповсюдженні серед окремих споживачів, а не через третю сторону, таку як засоби масової інформації. Однією 3 використовуваних систем доставки є пошта, електронна пошта, соціальні мережі та текстові повідомлення. Прямий маркетинг, як правило, усуває посередників, таких як рекламні носії.

На відміну від традиційних кампаній із зв'язків з громадськістю, які просуваються через третю сторону, таку як публікації в засобах масової інформації, кампанії прямого маркетингу діють незалежно для прямого спілкування з цільо- вою аудиторією. У прямому маркетингу компанії пропонують свої повідомлення та продажі за допомогою соціальних мереж, електронної пошти, пошти або телефронних/SMS-кампаній. Хоча кількість надісланих повідомлень може бути великою, прямий маркетинг часто намагається персоналізувати повідомлення, вставляючи ім'я або місто одержувача на видному місці, щоб збільшити зацікавленість.

Заклик до дії $є$ важливою частиною прямого маркетингу. Одержувачу повідомлення пропонується негайно відповісти, зателефонувавши на безкоштовний номер телефону, надіславши картку відповіді або натиснувши посилання в соціальній мережі або рекламному листі. Будь-яка відповідь є позитивним показником потенційного покупця. Цей різновид прямого маркетингу часто називають маркетингом прямої відповіді.

У прямого маркетингу як інтерактивної маркетингової системи розподілу туристичних послуг є переваги та недоліки. Прямий маркетинг - один 3 найпопулярніших та ефеективних маркетингових інструментів для встановлення прямого зв'язку з цільовою аудиторією. Прямий маркетинг має свою привабливість, особливо для компаній з обмеженим бюджетом, які не можуть дозволити собі оплачувати телевізійні або Інтернет-рекламні кампанії. Особливо у міру того, як світ стає все більш пов'язаним за допомогою цифрових платформ, соціальні медіа стають ефективним способом просування до клієнтів. Однак основним недоліком прямого маркетингу $€$ створення іміджу, що поставляється разом із третьою стороною, що акредитує бренд.

Для більш детального розкриття теми дослідження, розглянемо як використовувати прямий маркетинг як інтерактивну маркетингову систему розподілу туристичних послуг. Якщо підприємство займається гостинністю, подорожами та туристичними послугами необхідно просувати свій бізнес туди, куди

Динаміка туристичних потоків в Україні, осіб

Таблиця 1

\begin{tabular}{|l|c|c|c|c|c|c|}
\hline \multicolumn{1}{|c|}{ Показники } & \multicolumn{5}{|c|}{ Роки } & $\begin{array}{c}\text { Відхилення } \\
\text { (+l-) 2019 p. } \\
\text { до 2015 p. }\end{array}$ \\
\cline { 2 - 7 } & $\mathbf{2 0 1 5}$ & $\mathbf{2 0 1 6}$ & $\mathbf{2 0 1 7}$ & $\mathbf{2 0 1 8}$ & $\mathbf{2 0 1 9}$ & 4112521 \\
\hline $\begin{array}{l}\text { Кількість туристів, } \\
\text { обслугованих туроператорами } \\
\text { та турагентами, всього }\end{array}$ & 2019576 & 2549606 & 2806426 & 4557447 & 6142097 & 71681 \\
\hline $\begin{array}{l}\text { в тому числі } \\
\text { в'їзні (іноземні) туристи }\end{array}$ & 15159 & 35071 & 39605 & 75945 & 86840 & 3877476 \\
\hline виїзні туристи & 1647390 & 2060974 & 2289854 & 4024703 & 5524866 & 163364 \\
\hline внутрішні туристи & 357027 & 453561 & 476967 & 456799 & 520391 & 1 \\
\hline
\end{tabular}

Джерело: складено автором за даними Державної служби статистики України 
йдуть потенційні клієнти. Зокрема, при управлінні рестораном рекламувати за допомогою листівок у місцевих пансіонатах, магазинах та інших підприємствах, які, швидше за все, відвідають туристи. Якщо компанія пропонує послуги «ліжко та сніданок», необхідно використовувати буклети та листівки в ресторанах, барах і навіть на автозаправках. Необхідно проаналізувати, де туристи, швидше за все, будуть робити покупки, їсти та відвідувати визначні місця. Брошури дають компанії можливість продемонструвати номери та послуги, а також визначні пам'ятки в околицях.

Розвиток технічних можливостей маркетингу комунікації, зміни в поведінці аудиторії та здатності користуватися нею, наявні передові інструменти не завжди відповідають можливостям, поглядам та реальності комунікаторів. Галузеві та регіональні особливості, як правило, поглиблюють ці розбіжності. Хорошим прикладом цього можуть бути туристичні напрямки та їх багатонаціональний характер. Масове спілкування - це лише крок до маркетингової комунікації.

На рис. 1 проаналізовано технології цисррового прямого маркетингу в сорері надання туристичних послуг.

Можемо стверджувати, що маркетингове спілкування як інструмент, призначений для забезпечення комунікації між двома сторо- нами ринку - попитом і пропозицією. Тому суть маркетингового спілкування полягає у навмисному впливі на людей.

Канали розповсюдження дозволяють клієнтам купувати або отримувати доступ до туристичних продуктів. Тому вони можуть посилатися на всі аспекти зв'язку між підприємствами та їх клієнтами (будь то окремі споживачі, групи чи корпоративні клієнти). За останні п'ятдесят років постачальники туристичних послуг та їх посередники використовували технології для розповсюдження своєї продукції та послуг. Багато готелів та компаній з прокату автомобілів все ще використовують глобальні системи дистрибуції, щоб продавати свою продукцію клієнтам. Цей розділ припускає, що завтрашній бізнес повинен продовжувати впроваджувати інноваційні технології розповсюдження, щоб покращити свій досвід клієнтів.

Сьогодні найпоширеніший спосіб придбання туристичних продуктів, включаючи авіаперельоти, прокат автомобілів, круїзи, проживання в готелях та інші види транспорту, здійснюється через он-лайн та мобільні пошукові системи. Через велику кількість споживачів все частіше організовують подорожі через мобільний телесрон, екрани смартфонів і простіші способи оплати. Більше того, багато туристичних підприємств та он-лайн туристичні агентства покращили свої веб-сайти і, можливо, впро-

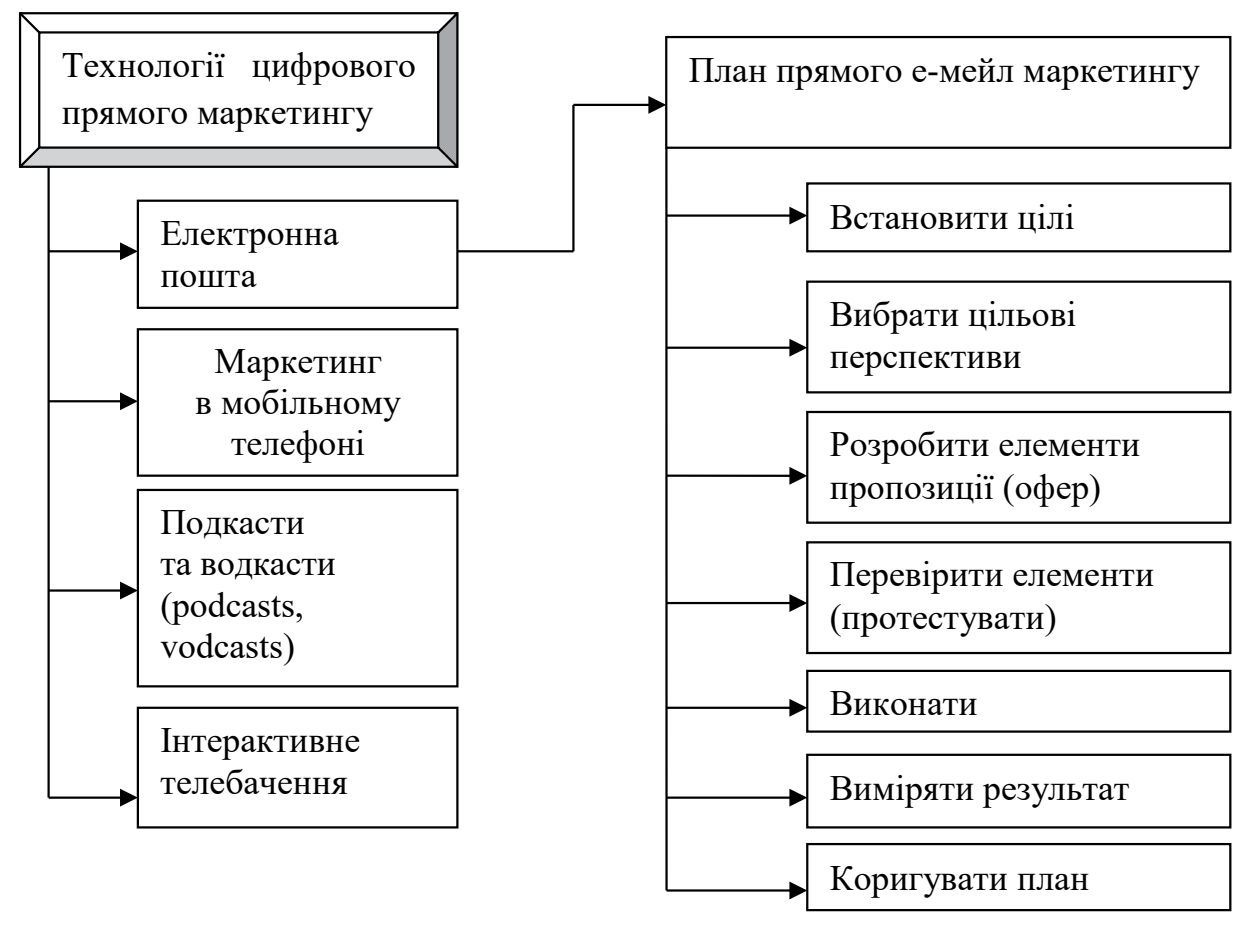

Рис. 1. Технології цифррового прямого маркетингу в сфері надання туристичних послуг

Джерело: власна розробка автора 
вадили зручні мобільні додатки. В результаті багато потенційних мандрівників не тільки бронюють свої поїздки в Інтернеті; але вони також шукають свої маршрути, коли вони там і там, за допомогою мобільного пристрою.

Корпоративні веб-сайти допомагають туристичним компаніям у їх стратегіях розповсюдження, оскільки вони покращують конверсії продажів. Чітка, диференційована інфрормація про ціни на послуги, надає потенційним клієнтам можливості вивчення продукту. Туристичний бізнес повинен зосередитися на вигодах, які вони надають, виділяючи свої ціннісні пропозиції; а не просто ілюструвати особливості своєї продукції.

Незважаючи на те, що так багато транзакцій здійснюється через Інтернет, відсутність особистої взаємодії в цьому середовищі означає, що навіть найменша річ, яка недоречна на сторінках електронної комерції, може швидко підірвати довіру клієнтів до продуктів та бізнесу. Тому підприємства можуть зміцнити довіру та довіру споживачів, використовуючи сертисрікат SSL для забезпечення безпеки транзакцій, особливо якщо вони обробляють кредитні картки.

Очікується, що інтернет-компанії сорормулюють свої умови, включаючи будь-які відповідні правила скасування та повернення коштів. Крім того, компанії, орієнтовані на клієнтів, повинні надавати клієнтам свої контактні дані (включаючи адресу, телефон та електронні листи). Багато онлайн-сайтів все частіше пропонують на своєму веб-сайті засоби чату, щоб допомогти потенційним клієнтам у їх запитах або вирішити їх проблеми. Якщо підприємства не пропонують таку взаємодію в режимі реального часу, вони все одно повинні визнати повідомлення своїх потенційних клієнтів в Інтернеті та повідомити їх, що вони будуть відповідати на них у розумні терміни. Крім того, використання відгуків споживачів, у тому числі; огляди та оцінки послужать доказом того, що туристичний бізнес забезпечує належний рівень обслуговування своїх клієнтів. Позитивний досвід самих клієнтів допоможе покращити конверсії та продажі.

Користувачі мережі можуть не захотіти взяти на себе зобов'язання відразу купувати товари. Тому підприємства могли б спонукати відвідувачів заповнити список абонентів для отримання ексклюзивних пропозицій елек- тронною поштою. Таким чином, підприємства зможуть пізніше надсилати інфрормаційні бюлетені та рекламні матеріали до потенційних клієнтів в Інтернеті.

Компанії повинні сприяти їх покупкам в Інтернеті та підтвердженню транзакцій. Складна воронка може стримувати конвертацію потенційних клієнтів. Клієнтам, які перебувають на сторінці оформлення замовлення, слід дозволити максимально швидко та ефективно завершити покупку. Якщо їхній досвід покупців, які здійснюють покупку в Інтернеті, передбачає зайві зусилля щодо виходу з веб-сайту; вони можуть замислитися над якістю послуг компанії. Тому користувачів не слід відволікати на те, що відволікає їх від послідовності покупок бізнесу. Важливо дати клієнтам завершити свою транзакцію, перш ніж розмістити їх у будь-якому іншому місці на веб -сайті. Багато пошукових систем все частіше пропонують вигідні пропозиції щодо туристичних продуктів. Дуже часто вони можуть мати зручний веб-сайт, що допомагає окремим споживачам шукати найкращі ціни.

Пошукові системи дозволять своїм користувачам встановлювати цінові сповіщення про туристичні продукти. Так, після того, як користувачі повідомлять деталі про дати поїздки та свою електронну адресу, вони будуть отримувати регулярні електронні листи, які повідомлятимуть про те, чи зросла чи знизилася ціна на рейс (який шукали в пошукових системах). Сповіщення про подорожі зручні для тих пасажирів, які планують свій маршрут заздалегідь.

У найближчому майбутньому туристичний ринок обов'язково впровадить нові технології та можливості; оскільки багато фрірм венчурного капіталу все більше інвестують у інновації. Отже, туристичному бізнесу потрібно шукати шляхи, які навмисно скасовують десятиліття застарілої практики розподілу подорожей.

Висновки. Концепція прямого маркетингу туристичних послуг орієнтована на надання клієнту якісного обслуговування. Мірою успіху його впровадження $€$ високий рівень задоволеності клієнтів протягом тривалого часу. Туристична фрірма, що реалізує концепцію прямого маркетингу, прагне таким чином пов'язати свої інтереси розвитку, прибутку тощо 3 інтересами споживачів туристичних послуг, 3 їх споживчою поведінкою. Отже, туристична компанія на сучасному ринку.

\section{СПИСОК ВИКОРИСТАНИХ ДЖЕРЕЛ:}

1. Державний сайт статистики України. URL: http://www.ukrstat.gov.ua/

2. Blerim, K. (2012) The marketing of the craft products in Albania, The effects of web Marketing. European Scientific Journal, 8(3). URL: https://eujournal. org/index.php/esj/article/view/52 
3. Holleran, M. (2020) Tourism, Urbanization, and the Evolving Periphery of the European Union. Palgrave Pivot, Singapore. DOI: https://doi.org/10.1007/978-981-15-0218-7

4. Polyakov, M. Bilozubenko, V. Nebaba, N. Korneyev M. and Saihak Y. (2020) Analysis of asymmetry factors in the development of the EUtourism industry. Innovative Marketing, 16(4), 117-128. DOI: https://doi.org/10.21511/im.16(4).2020.10

5. Royle, J., \& Laing, A. (2014) The digital marketing skills gap: Developing a Digital Marketer Model for the communication industries. International Journal of Information Management, 34(2), 65-73. DOI: https://doi.org/ 10.1016/j.ijinfomgt.2013.11.008

6. Sushchenko O. and Ekouaghe M. (2019) Trends in the development of marketing technologies in the tourism market. Economics of Development, 18(1), 9-22. DOI: https://doi.org/10.21511/ed.18(1).2019.02

7. Ungerman, O., Dedkova, J., \& Gurinova, K. (2018) The impact of marketing innovation on the competitiveness of enterprises in the context of Industry 4.0. Journal of Competitiveness, 10(2), 132-148. DOI: https://doi.org/10.7441/ joc.2018.02.09

8. Vaculčikova, Z. Tučkova and Xuan Thanh Nguyen (2020) Digital marketing access as a source of competitiveness in traditional Vietnamese handicraft villages. Innovative Marketing, 16(1), 1-10. DOI: https://doi.org/ 10.21511/im.16(1).2020.01

9. WTTC (2019), "Travel \& Tourism continues strong growth above global GDP (press release WTTC)". URL: https://www.wttc.org/about/mediacentre/press-releases/press-releases/2019/travel-tourism-continues-stronggrowthabove-global-gdp

10. Bezuhla L., Demchuk N. (2019) Development strategy of ecoturism enterprises as a factor of increasing their competitiveness. Organizational-economic mechanism of management innovative development of economic entities : Collective monograph / edited by M. Bezpartochnyi, in 3 vol. / Higher School of Social and Economic. Przewosk: WSSG. Vol. 2. P. 289-297.

11. Безугла Л.С. Соціально-економічні фрункції держави щодо розвитку малого та середнього підприємництва в Україні. Державне управління: удосконалення та розвиток. 2011. № 2. URL: http://nbuv.gov.ua/UJRN/ Duur_2011_2_5

\section{REFERENCES:}

1. Official website of the State Statistics Committee. Retrieved from: www.ukrstat.gov.ua

2. Blerim, K. (2012) The marketing of the craft products in Albania. The effects of web Marketing. European Scientific Journal, 8(3). Retrieved from: https://eujournal.org/index.php/esj/article/view/52

3. Holleran, M. (2020) Tourism, Urbanization, and the Evolving Periphery of the European Union. Palgrave Pivot, Singapore. DOI: https://doi.org/10.1007/978-981-15-0218-7

4. Polyakov M., Bilozubenko V., Nebaba N., Korneyev M. and Saihak Y. (2020) Analysis of asymmetry factors in the development of the EU tourism industry. Innovative Marketing, 16(4), 117-128. DOI: https://doi.org/10.21511/im.16(4).2020.10

5. Royle, J., \& Laing, A. (2014) The digital marketing skills gap: Developing a Digital Marketer Model for the communication industries. International Journal of Information Management, 34(2), 65-73. DOI: https://doi.org/10.1016/ j.ijinfomgt.2013.11.008

6. Sushchenko O. and Ekouaghe M. (2019) Trends in the development of marketing technologies in the tourism market. Economics of Development, 18(1), 9-22. DOI: https://doi.org/10.21511/ed.18(1).2019.02

7. Ungerman, O., Dedkova, J., \& Gurinova, K. (2018) The impact of marketing innovation on the competitiveness of enterprises in the context of Industry 4.0. Journal of Competitiveness, 10(2), 132-148. DOI: https://doi.org/ 10.7441/joc.2018.02.09

8. Vaculčikova, Z. Tučkova and Xuan Thanh Nguyen (2020) Digital marketing access as a source of competitiveness in traditional Vietnamese handicraft villages. Innovative Marketing, 16(1), 1-10. DOI: https://doi.org/10.21511/ im.16(1).2020.01

9. WTTC (2019) "Travel \& Tourism continues strong growth above global GDP (press release WTTC)". Retrieved from: https://www.wttc.org/about/mediacentre/press-releases/press-releases/2019/travel-tourism-continues-stronggrowth-above-global-gdp

10. Bezuhla L., Demchuk N. (2019) Development strategy of ecoturism enterprises as a factor of increasing their competitiveness. Organizational-economic mechanism of management innovative development of economic entities: Collective monograph / edited by M. Bezpartochnyi, in 3 vol. / Higher School of Social and Economic. Przewosk: WSSG, vol. 2, pp. 289-297.

11.Bezuhla, L.S. (2011) Sotsialno-ekonomichni funktsii derzhavy schodo rozvytku maloho ta serednoho pidpryiemnytstva $v$ Ukraini [Socio-economic functions of the state for the development of small and medium enterprises in Ukraine]. Derzhavne upravlinnia: udoskonalennia ta rozvytok - Public administration: improvement and development, vol. 2. Retrieved from: http://nbuv.gov.ua/UJRN/Duur_2011_2_5 (in Ukrainian) 